\title{
Doğum Sonu Dönemde Emziren Kadınların Cinsel Yaşam Kalitesi
}

\author{
Elif Şahbaz Selimoğlu'®®, Kerime Derya Beydağ²®
}

1̇istanbul Florence Nigtingale Hastanesi, İstanbul, Türkiye ${ }^{2}$ istanbul Okan Üniversitesi, Sağlık Bilimleri Fakültesi, Hemşirelik, Istanbul, Türkiye

Elif Şahbaz Selimoğlu, Uzm. Hemş. Kerime Derya Beydağ, Doç. Dr.

\section{iletişim:}

Doç. Dr. Kerime Derya Beydağ

İstanbul Okan Üniversitesi, Sağılı Bilimleri

Fakültesi, Hemşirelik, Istanbul, Türkiye

Tel: +90216677 1630/3849

E-Posta: derya.beydag@okan.edu.tr

Gönderilme Tarihi : 24 Mayıs 2018

Revizyon Tarihi : 25 Eylül 2018

Kabul Tarihi : : 04 Şubat 2019

\section{ÖZET}

Amaç: Bu çalışma, doğum sonrasında bebeğini emziren kadınlarda, emzirmenin cinsel yaşamına etkisini belirlemek amacıyla yapılmıştır.

Çalışma planı: Tanımlayıı ve kesitsel nitelikteki çalışmanın evrenini, İstanbul'un Avrupa yakasında hizmet veren bir özel hastanenin kadın doğum polikliniğine Ekim-Aralık 2017 tarihleri arasında başvuran, doğum sonrası 0-6 ay arası dönemde olan ve bebeğini emziren 172 kadın oluşturmuştur. Çalışmada örneklem seçilmeden evren üzerinde çalışılmak istenmiş, ancak çalışmaya katılmak istemeyenler ve eksik doldurulmuş anketler olması nedeniyle, 104 kadın örneklemi oluşturmuştur. Veriler, sosyo-demografik veri formu ve Türkçe güvenirlik çalışması Tuğut ve Gölbaşı tarafından 2010 yılında yapıımış olan "Cinsel Yaşam Kalitesi Ölçeği'kullanılarak elde edilmiştir. Verilerin değerlendirilmesinde, sayı-yüzdelik hesaplamaları Kruskal-wallis, Mann-whitney U testi ve t testi kullanıımıştır.

Bulgular: Kadınların CYKÖ puan ortalaması 60,43 $\pm 10,70$ olarak bulunmuştur. Katılımcıların, doğumun üzerinden geçen süre, doğum şekli, günlük ortalama emzirme sayısı, emzirmeyi etkileyebilecek meme sorunu olma durumu, şimdiye kadar cinsel yaşamı sırasında cinsel aktiviteyi engelleyen bir durum olma durumu, gebelik öncesi ve gebelik sırasında cinsel yaşamla ilgili herhangi bir sorun yaşama durumu, doğum sonu cinsellik yaşamaya başlama zamanı, bebeğini emzirdiği süre içerisinde ayda kaç kez cinsel ilişkiye girdiği ve cinsel yaşam hakkında bilgi alma durumu ile CYKÖ puan ortalaması arasında istatistiksel açıdan anlamlı farkılık saptanmamıştır $(p>0,05)$. Katılımcıların doğum sonu dönemde cinsel yaşamla ilgili herhangi bir sorun yaşama durumu ve doğumdan sonra cinsel ilişkiyi başlatmayı kimin teklif ettiği ile CYKÖ puan ortalaması arasında istatistiksel açıdan anlamlı farklıık saptanmıştır $(p<0,05)$. Doğum sonu dönemde cinsel yaşamla ilgili sorun yaşamadığııı belirten ve eşi ile birlikte cinsel aktiviteyi başlamayı isteyenlerin CYKö puanlarının daha yüksek olduğu, cinsel yaşam kalitelerinin daha yüksek olduğu belirlenmiştir.

Sonuç: Hemşire ve ebelerin, emzirme döneminde kadınların cinsel yaşam kalitesini değerlendirerek ve gereksinim duyanları ilgili birimlere yönlendirmesi önerilmektedir.

Anahtar sözcükler: Doğum sonu, emzirme, cinsel yaşam, cinsel yaşam kalitesi

\section{THE IMPACT OF BREASTFEEDING ON SEXUAL LIFE QUALITY IN POSTPARTUM PERIODS}

\section{ABSTRACT}

Aim: This study was conducted to determine the effect of breastfeeding on the sexual life of women who breastfeed their baby after childbirth.

Study design: The universe of the descriptive and cross-sectional study consisted of 172 women admitted to the gynecology clinic of a private hospital serving the European side of Istanbul between 0ctober and December 2017, who were between 0-6 months postpartum and breastfeeding their babies. Only 104 women were included in the study because the rest eitherdid not want to participate in the study or they inadequately filled the surveys. The data were obtained using the socio-demographic data form and the Turkish Sexual Life Quality Scale (SLQS) conducted by Tuğut and Gölbaşı in 2010. In the evaluation of the data, KruskalWallis, Mann-Whitney $\mathrm{U}$ test and $\mathrm{t}$-test were used for number-percentage calculations.

Results: The average score of women was found as $60.43 \pm 10.70$. The number of participants, their time of birth, the type of delivery, the average number of daily breastfeeding, the breast problem that can affect the breast milk, the condition that prevents sexual activity during sexual life up to now, any problems with sexual life before and during pregnancy were included. There was no statistically significant difference between the meantime to start sexuality, the number of sexual intercourse per month during the period of breastfeeding the baby, and the status of getting informed about sexual life and SLQS point average $(p>0.05)$. There was a statistically significant difference between participants' $p$ stpartum sexual life status and postpartum who started sexual intercourse and SLQS score average $(p<0.05)$. It was determined that those who stated that they did not have any problems related to sexual life in the postpartum period and those who want to start a sexual activity with their husbands have higher SLQS scores and higher sexual life qualities.

Conclusion: It is recommended that nurses and midwives evaluate the quality of the breastfeeding women'sexual life during the breastfeeding period and refer them to the relevant units.

Keywords: Postpartum, breastfeeding, sexual life, sexual life quality 
insellik, bireyin cinsiyeti ile ilgili tüm konuları içeren kapsamlı bir kavramdır. Bireyin cinsel yaşamı biyolojik, psikolojik, sosyoekonomik, kültürel, etik ve dini faktörlerden etkilenmektedir. Cinsellik hayatın farklı evrelerinde değişiklik göstermektedir. Doğum sonrası dönem de bu evrelerden birisidir (1-3).

Doğum sonrası dönemde cinsel ilişkiye başlama zamanı kadının fiziksel olarak iyileşmesine ve her iki eşin psikolojik olarak hazır olmasına bağlıdır. Kanama ve enfeksiyon riskinin azaldığı ikinci haftadan sonra cinsel aktiviteye başlanabilir (4). Doğum sonrası cinsel ilişkinin yeniden başlaması kültürlere göre değişiklik göstermektedir. Ülkemizde doğumdan sonra cinsel ilişkiye başlama zamanı geleneksel olarak altı haftadır. Türkiye'de yapılan çalışmalarda kadınların çoğunun postpartum altıncı haftada cinsel ilişkiye başladıkları bildirilmektedir.

Doğum sonrası dönemde kadınların bebeklerini emzirmeleri, anne-bebek iletişiminin sağlanması ve bebeklerin gelişimi için çok önemlidir. Emziren ve emzirmeyen kadınların doğum sonrası cinsel yaşamlarında farklılıklar olmaktadır. Bu farklılık emziren annelerde süt yapımını sağlamak için prolaktin ve oksitosin salınımlarının emzirmeyen annelere göre fazla olmasından kaynaklanmaktadır (5-8). Bazı çalışmalarda emzirmenin, kadınların kendilerini daha seksi hissetmelerini sağlayarak, cinsel isteklerini arttırarak ve orgazm olmalarını kolaylaştırarak doğum sonrası dönemde cinsel yaşam üzerinde olumlu etki yarattığı bulunmuştur $(9,10)$. Avery ve ark. (2000) kadınların doğum sonrasında memelerindeki hassasiyet ve ağrı hissinden dolayı cinsel ilişkiden daha fazla haz duyduklarını bildirmişlerdir (10). Fakat bazı çalışmalarda ise emzirmenin, cinsel isteği, cinsel ilgiyi, disparanoya oluşumunu etkileyerek ve cinsel yaşamdan memnuniyeti azaltarak doğum sonrası cinsel yaşamı olumsuz yönde etkilediği belirtilmektedir. (11-14). Akyüz'ün çalışmasında (2009), kadınların \%14,3'ü doğum sonrası dönemde memelerinde oluşan değişikliklerden dolayı cinsel ilişki esnasında rahatsızlık hissettiklerini ifade etmişlerdir (15). Benzer bir çalışmada La Marre ve ark. (2003) kadınların memelerinden süt gelmesinin cinselliklerini olumsuz etkilediğini rapor etmişlerdir (16).

Hemşire ve ebenin doğum sonrası dönemde kadınların cinsel sağlıklarını yükseltmek için veri toplama, cinsel problemleri saptama ve bu problemlere yönelik eğitim ve danışmanlık yapma sorumlulukları bulunmaktadır. Doğum sonrası oluşan tüm değişikliklere çiftlerin uyum sağlayarak cinsel yaşamlarına yeniden başlamayı sağlamada ve sürdürmede hemşirelerin ve ebelerin danışmanlık hizmetleri önemlidir. Hemşirelerin ve ebelerin etkili bir dinleyici olması, kadının endişelerine dikkat etmesi, etkin soru sormaSı, sezgi ve algılama yeteneğini kullanması kadının cinsel problemlerini saptamaya yardımcı olmaktadır (17).

Bu çalışma, doğum sonu dönemde kadınların cinsel yaşam kalitesi üzerine emzirmenin etkisini belirlemek amacıyla yapılmıştır.

\section{Gereç ve yöntem}

Araştırmanın tipi ve yeri: Tanımlayıcı ve kesitsel nitelikte yapılmış olan çalışma, İstanbul'un Avrupa yakasında hizmet veren bir özel hastanenin kadın hastalıkları ve doğum polikliniğine, Ekim-Aralık 2017 tarihleri arasında başvuran ve çalışmaya katılmayı kabul eden, Türkçe konuşup anlaşabilen, okuma yazma bilen ve kendisinde ruhsal bir sorun olmayan kadınlarla gerçekleştirilmiştir. Çalışmanın yürütüldüğü hastane, Avrupa yakasında merkez konumunda olan ve her sosyoekonomik düzeyden ailenin başvuru yaptığı bir hastanedir.

\section{Araştırmanın evren ve örneklemi}

Araştırmanın evrenini, 0-6 aylık bebeği olan ve bebeğini emziren 172 kadın oluşturmuştur. Örneklem seçilmeden evren üzerinde çalışılmak istenmiş, ancak bazı kadınların çalışmaya katılmayı kabul etmemesi, eksik doldurulmuş anketler olması nedeniyle 104 kişi $(\% 60,5)$ örnekleme dâhil edilmiştir. Çalışmaya katılmayı kabul etmeyen kadınlar, zamanları olmadığını ya da sorulara yanıt vermeyi istemediklerini belirtmiştir.

\section{Veri toplama araçları}

Araştırma verileri, sosyo-demografik veri formu ve Cinsel Yaşam Kalitesi Ölçeği "ile elde edilmiştir. Anket formları, muayene öncesi bekleme zamanlarında kadınların kendilerine verilerek doldurmaları istenmiş, anket bittikten sonra araştırmacı tarafından teslim alınmıştır. Veri toplama süresi yaklaşık olarak 10 dakika kadar sürmüştür. Cinsel Yaşam Kalitesi Ölçeği'nin Türkçe güvenirlik çalışması Tuğut ve Gölbaşı tarafından 2010 yılında yapılmıştır. Ölçek, '1=tamamen katılıyorum', '2=Büyük ölçüde katılıyorum' , '3=kısmen katılıyorum' , "4=kısmen katılmıyorum”, ‘5=büyük ölçüde katılmıyorum' , '6=hiç katılmıyorum' şeklinde altılı likert tipinde olup, 18 maddeden oluşmaktadır. Her bir maddenin son dört hafta içerisindeki cinsel yaşamı düşünülerek yanıtlanması beklenmektedir. Ölçeğin puanlamasında her soru 1-6 arasında puanlanmaktadır. Ölçekten alınabilecek puan aralığı, 18-108 arasındadır. Toplam puan hesaplanmadan önce 1, 5, 9, 13 ve 18 numaralı maddelerin puanlarının tersine çevrilmesi 
gerekmektedir. Toplam ölçek puanının 100'e dönüştürülmesi için (ölçekten alınan ham puan-18) x100/90 formülünün kullanılması gerekmektedir. Ölçekten alınan puanın yüksek olması cinsel yaşam kalitesinin iyi olduğunu göstermektedir. Tugut ve Gölbaşı'nın (2010) çalışmasında ölçeğin Cronbach's alfa katsayısı 0,83 olarak hesaplanmıştır (18). Bu çalışmada ölçeğin Cronbach's alfa katsayısı 0,81 olarak bulunmuştur.

\section{Verilerin değerlendirilmesi}

Araştırmada elde edilen veriler SPSS (Statistical Package for Social Sciences) for Windows 22.0 programı kullanılarak analiz edilmiştir. Verilerin tanımlayıcı istatistiklerinde ortalama, standart sapma, medyan en düşük, en yüksek, frekans ve oran değerleri kullanılmıştır. Değişkenlerin dağılımı Kolmogorov Simirnov test ile ölçülmüş, nicel verilerin analizinde Kruskal-Wallis, Mann-Whitney $\mathrm{U}$ testi ve $\mathrm{t}$ testi kullanılmıştır. Elde edilen bulgular \%95 güven aralığında, \%5 anlamlılık düzeyinde değerlendirilmiştir.

Veri toplama işlemi öncesinde, ölçeğin Türkçe geçerlik ve güvenirlik çalışmasını yapan Gölbaşı'ndan mail ile ölçek kullanım izni alınmış, Okan Üniversitesi Etik Kurul Onayı 19,10,2016 tarih ve 77 sayılı kararı ile alınmıştır. Çalışmaya katılan kadınlara, çalışma hakkında bilgi verilmiş ve çalışma öncesinde yazılı onamları alınmıştır.

\section{Bulgular}

Çalışma kapsamında yer alan kadınların \%50'sinin 31 yaş ve üzeri yaş grubunda, $\% 63,5^{\prime}$ nin $1-5$ yıldır evli ve \%51,9'unun ilköğretim mezunu saptanmıştır. Kadınların $\% 53,8$ 'i ev hanımı ve \%90,4'ü çekirdek aileye sahiptir.

Araştırmaya katılan kadınların gebelik ve emzirmeye ilişkin özelliklerinin dağılımı Tablo 1 'de gösterilmiştir. Kadınların $\% 63,5^{\prime}$ inin ilk gebeliği olduğu, \%86,5'inin gebeliği istediği, \%54,8'inin 6-10 hafta önce doğum yaptığı belirlenmiştir. Kadınların \%55,8'i sezaryen doğum yaptığını, \%51,9'u günde ortalama 2-8 kez bebeğini emzirdiğini belirtmiştir.

Araştırmaya katılan kadınların cinsel yaşamlarına ilişkin sorulara verdikleri yanıtların dağılımları Tablo 2'de gösterilmiştir. Kadınların \%93,3'ü şimdiye kadar cinsel yaşamı sırasında cinsel aktiviteyi engelleyen bir durum yaşamadığını, \%97,1'i gebelik öncesi cinsel yaşamla ilgili herhangi bir sorun yaşamadığını ve $\% 78,8^{\prime} i$ doğum sonu dönemde cinsel yaşamla ilgili herhangi bir sorun yaşamadığını ifade etmiştir. Kadınların \%69,2'sinin doğum sonu 41'nci günden sonra cinsel aktiviteye başladığı, $\% 48,1^{1}$ 'inin doğum sonu dönemde cinsel ilişkiyi başlatmayı çoğunlukla eşinin
Tablo1. Katıımcıların gebelik ve emzirmeye ilişkin özelliklerine göre dağlımları

\begin{tabular}{llcc} 
Değişkenler & & Sayı (n) & Yüzde (\%) \\
\hline Gebelik Sayısı & İlk & 66 & 63,5 \\
& İkinci & 31 & 29,8 \\
& Üç ve üzeri & 7 & 6,7 \\
\hline Gebeliğin istenme durumu & İstenen & 90 & 86,5 \\
& İstenmeyen & 14 & 13,5 \\
\hline Doğumun üzerinden & 6-10 hafta & 57 & 54,8 \\
ne kadar süre geçtiği & 11 hafta ve üzeri & 47 & 45,2 \\
\hline Doğum Şekli & Normal doğum & 46 & 44,2 \\
\hline Günlük ortalama & Sezaryan & 58 & 55,8 \\
emzirme sayısı & 2-8 kez & 54 & 51,9 \\
& 9-15 kez & 50 & 48,1 \\
& Toplam & 104 & 100,0
\end{tabular}

Tablo 2. Katılımcıların cinsel yaşamlarına ilişkin sorulara verdikleri yanıtların dağılımı

\begin{tabular}{|c|c|c|c|}
\hline \multicolumn{2}{|l|}{ Değişkenler } & \multicolumn{2}{|c|}{ Sayı Yüzde } \\
\hline \multirow{2}{*}{$\begin{array}{l}\text { Şimdiye kadar cinsel yaşamı sırasında } \\
\text { cinsel aktiviteyi engelleyen bir durum } \\
\text { olma durumu }\end{array}$} & Oldu & 7 & 6,7 \\
\hline & Olmadı & 97 & 93,3 \\
\hline \multirow{2}{*}{$\begin{array}{l}\text { Gebelik öncesi cinsel yaşamla ilgili } \\
\text { herhangi bir sorun yaşama durumu }\end{array}$} & Yaşayan & 3 & 2,9 \\
\hline & Yaşamayan & 101 & 97,1 \\
\hline \multirow{2}{*}{$\begin{array}{l}\text { Gebelik sırasında cinsel yaşamla ilgili } \\
\text { herhangi bir sorun yaşama durumu }\end{array}$} & Yaşayan & 8 & 7,7 \\
\hline & Yaşamayan & 96 & 92,3 \\
\hline \multirow{2}{*}{$\begin{array}{l}\text { Doğum sonu dönemde cinsel yaşamla } \\
\text { ilgili herhangi bir sorun yaşama durumu }\end{array}$} & Yaşayan & 22 & 21,2 \\
\hline & Yaşamayan & 82 & 78,8 \\
\hline \multirow{2}{*}{$\begin{array}{l}\text { Doğum sonu cinsellik yaşamaya } \\
\text { başlama zamanı }\end{array}$} & 25-40 gün & 32 & 30,8 \\
\hline & 41 gün ve üzeri & 72 & 69,2 \\
\hline \multirow{3}{*}{$\begin{array}{l}\text { Doğumdan sonra cinsel ilişkiyi } \\
\text { başlatmayı kimin teklif ettiği }\end{array}$} & Çoğunlukla eşi & 60 & 48,1 \\
\hline & $\begin{array}{l}\text { Çoğunlukla } \\
\text { kendisi }\end{array}$ & 12 & 11,5 \\
\hline & Eşi ile birlikte & 42 & 40,4 \\
\hline \multirow{4}{*}{$\begin{array}{l}\text { Bebeğini emzirdiği süre içerisinde } \\
\text { ayda kaç kez cinsel ilişkiye girdiği }\end{array}$} & $1-3 \mathrm{kez}$ & 34 & 32,7 \\
\hline & 4-6 kez & 44 & 42,3 \\
\hline & 7-9 kez & 17 & 16,3 \\
\hline & 10 kez ve üzeri & 9 & 8,7 \\
\hline \multirow{5}{*}{$\begin{array}{l}\text { Bu güne kadar hiç doğum öncesi, } \\
\text { gebelik sırasında veya doğum sonrası } \\
\text { dönemlerdeki cinsel yaşam hakkında } \\
\text { bilgi alma durumu }\end{array}$} & Bilgi almayan & 10 & 9,6 \\
\hline & $\begin{array}{l}\text { Doktordan bilgi } \\
\text { alan }\end{array}$ & 67 & 64,4 \\
\hline & $\begin{array}{l}\text { Arkadaşından } \\
\text { bilgi alan }\end{array}$ & 4 & 3,8 \\
\hline & $\begin{array}{l}\text { Hemşire/ebeden } \\
\text { bilgi alan }\end{array}$ & 23 & 22,2 \\
\hline & Toplam & 104 & 100,0 \\
\hline
\end{tabular}


teklif ettiği ve \%42,3'ünün ayda 4-6 kez cinsel ilişkiye girdiği belirlenmiştir. Kadınların \%64,4'ü doktordan doğum öncesi, gebelik sırasında veya doğum sonrası dönemlerdeki cinsel yaşam hakkında bilgi aldığını belirtmiştir.

Kadınların Cinsel Yaşam Kalitesi Ölçeği (CYKÖ) Puan Ortalaması Tablo 3'te gösterilmiştir. Kadınların CYKÖ puan ortalaması $60,43 \pm 10,70$ olarak bulunmuştur.

Tablo 3. Katılımcıların cinsel yaşam kalitesi ölçeği (CYKÖ) puan ortalaması

\begin{tabular}{ccccc} 
& Ort & Ss & Min. & Max. \\
\hline Cinsel Yaşam Kalitesi Ölçeği & 60,43 & 10,70 & 23 & 88
\end{tabular}

\section{Tablo 4. Katllımclların demografik özelliklerine göre CYKÖ puan} ortalamalarının karşılaşııııması

\begin{tabular}{llccccc}
\multicolumn{2}{l}{ Değişkenler } & $\boldsymbol{n}$ & Ort & SS & Test* & $\boldsymbol{p}$ \\
\hline Yaş grubu & 18-30 yaş & 52 & 61,94 & 10,11 & t: 1,446 & 0,151 \\
& 31 yaş ve üzeri & 52 & 58,92 & 11,15 & & \\
\hline Evlilik & $1-5$ yıl & 66 & 60,27 & 10,15 & t:-0,200 & 0,842 \\
süresi & 6 yıl ve üzeri & 38 & 60,71 & 11,71 & & \\
\hline Öğrenim & Illköğretim & 54 & 60,94 & 11,39 & t:0,505 & 0,615 \\
durumu & Lise ve üzeri & 50 & 59,88 & 9,98 & & \\
\hline Çalışma & Çalışıyor & 48 & 60,10 & 11,49 & t:-0,289 & 0,773 \\
durumu & Çalışmıyor & 56 & 60,71 & 10,06 & & \\
\hline Aile tipi & Çekirdek aile & 94 & 60,38 & 10,30 & Z:-0,989 & 0,323 \\
& Geniş aile & 10 & 60,90 & 14,57 & & \\
\hline
\end{tabular}

*t: t testi, Z: Man Whitney U testi

Kadınların demografik özelliklerine göre CYKÖ puan ortalamalarının karşılaşsırılması Tablo 4'te gösterilmiştir. Katılımcıların, yaş grubu, evlilik süresi, öğrenim durumu, çalışma durumu ve aile tipi ile CYKÖ puan ortalaması arasında istatistiksel açıdan anlamlı farklılık saptanmamıştır $(p>0,05)$.

Kadınların gebelik ve emzirmeye ilişkin demografik özelliklerine göre CYKÖ puan ortalamalarının karşılaştırılması Tablo 5'te gösterilmiştir. Katılımcıların, gebelik sayısı, gebeliğin istenme durumu, doğumun üzerinden geçen süre, doğum şekli ve günlük ortalama emzirme sayısı ile CYKÖ puan ortalaması arasında istatistiksel açıdan anlamlı farklılık saptanmamıştır $(p>0,05)$.

Kadınların cinsel yaşamlarına ilişkin sorulara verdikleri yanıtlara göre CYKÖ puan ortalamalarının karşılaştırılması Tablo 6'da gösterilmiştir. Katılımcıların şimdiye kadar
Tablo 5. Katılımcıların gebelik ve emzirmeye ilişkin özelliklerine göre CYKÖ puan ortalamalarının karşılaştıııması

\begin{tabular}{|c|c|c|c|c|c|}
\hline Değişkenler & $n$ & Ort & SS & Test* & $p$ \\
\hline \multicolumn{6}{|l|}{ Gebelik Sayısı } \\
\hline illk & 66 & 59,43 & 10,48 & \multirow{3}{*}{ Kw: 2,929 } & \multirow{3}{*}{0,23} \\
\hline İkinci & 31 & 60,70 & 10,61 & & \\
\hline Üç ve üzeri & 7 & 68,57 & 11,10 & & \\
\hline \multicolumn{6}{|c|}{ Gebeliğin istenme durumu } \\
\hline İstenen & 90 & 60,86 & 10,24 & \multirow{2}{*}{ Z:-0,348 } & \multirow{2}{*}{0,728} \\
\hline İstenmeyen & 14 & 57,64 & 13,35 & & \\
\hline \multicolumn{6}{|c|}{$\begin{array}{l}\text { Doğumun üzerinden ne } \\
\text { kadar süre geçtiği }\end{array}$} \\
\hline $6-10$ hafta & 57 & 59,87 & 10,96 & \multirow{2}{*}{ t:- $-0,581$} & \multirow{2}{*}{0,562} \\
\hline 11 hafta ve üzeri & 47 & 61,10 & 10,44 & & \\
\hline \multicolumn{6}{|l|}{ Doğum Şekli } \\
\hline Normal doğum & 46 & 61,76 & 10,08 & \multirow{2}{*}{$\mathrm{t}: 1,129$} & \multirow{2}{*}{0,26} \\
\hline Sezaryan & 58 & 59,38 & 11,13 & & \\
\hline \multicolumn{6}{|l|}{$\begin{array}{l}\text { Günlük ortalama } \\
\text { emzirme sayısı }\end{array}$} \\
\hline 2-8 kez & 54 & 59,87 & 11,27 & \multirow{2}{*}{ t:-0,555 } & \multirow{2}{*}{0,580} \\
\hline 9-15 kez & 50 & 61,04 & 10,12 & & \\
\hline
\end{tabular}

cinsel yaşamı sırasında cinsel aktiviteyi engelleyen bir durum olma durumu, gebelik öncesi ve gebelik sırasında cinsel yaşamla ilgili herhangi bir sorun yaşama durumu, doğum sonu cinsellik yaşamaya başlama zamanı, bebeğini emzirdiği süre içerisinde ayda kaç kez cinsel ilişkiye girdiği ve cinsel yaşam hakkında bilgi alma durumu ile CYKÖ puan ortalaması arasında istatistiksel açıdan anlamlı farklılık saptanmamıştır $(p>0,05)$.

\section{Tartışma}

Kadınların \%93,3'ü şimdiye kadar cinsel yaşamı sırasında cinsel aktiviteyi engelleyen bir durum yaşamadığını, $\% 97,1^{\prime \prime i}$ gebelik öncesi cinsel yaşamla ilgili herhangi bir sorun yaşamadığını ve \%78,8'i doğum sonu dönemde cinsel yaşamla ilgili herhangi bir sorun yaşamadığını ifade etmiştir (Tablo 2). Bu sonuçlar, kadınların gebelik öncesi, sırasında cinsel yaşamlarının bu süreçten olumsuz etkilenmediğini, ancak her dört kadından birinin doğum sonu dönemde cinsel yaşamlarının olumsuz etkilendiğini göstermektedir. Çoban'ın (2012) çalışmasında, kadınların $\% 83,2$ 'si son gebeliklerinde cinsel yaşamı etkileyen sağlık sorunu yaşamadığını ifade ederken; \%66,4'ü doğum sonu dönemde sorun yaşadığını ifade etmiştir (19). Değerli Kodaz'ın (2013) çalışmasında kadınların \%78,2'si gebelikte cinsel yaşam ile ilgili sıkıntı yaşamadığını belirtmiştir (20). 
Tablo 6. Katılımcıların cinsel yaşamlarına ilişkin sorulara verdikleri yanıtlara göre CYKÖ puan ortalamalarının karşılaştıııması

\begin{tabular}{|c|c|c|c|c|c|c|}
\hline Değişkenler & & $n$ & Ort & SS & Test* & $p$ \\
\hline \multirow{2}{*}{$\begin{array}{l}\text { Şimdiye kadar cinsel yaşamı sırasında } \\
\text { cinsel aktiviteyi engelleyen bir durum olma durumu }\end{array}$} & Oldu & 7 & 61,00 & 17,12 & $Z:-0,195$ & 0,845 \\
\hline & Olmadı & 97 & 6038 & 10,22 & & \\
\hline \multirow{2}{*}{$\begin{array}{l}\text { Gebelik öncesi cinsel yaşamla ilgili herhangi bir } \\
\text { sorun yaşama durumu }\end{array}$} & Yaşayan & 3 & 58,00 & 19,07 & $Z:-0,457$ & 0,648 \\
\hline & Yaşamayan & 101 & 60,50 & 10,51 & & \\
\hline \multirow{2}{*}{$\begin{array}{l}\text { Gebelik sırasında cinsel yaşamla ilgili herhangi bir } \\
\text { sorun yaşama durumu }\end{array}$} & Yaşayan & 8 & 60,50 & 16,06 & $Z:-0,031$ & 0,976 \\
\hline & Yaşamayan & 96 & 60,42 & 10,25 & & \\
\hline \multirow[t]{2}{*}{ Doğum sonu cinsellik yaşamaya başlama zamanı } & 25-40 gün & 32 & 62,21 & 10,11 & $\mathrm{t}: 1,136$ & 0,258 \\
\hline & 41 gün ve üzeri & 72 & 59,63 & 10,92 & & \\
\hline \multirow{4}{*}{$\begin{array}{l}\text { Bebeğini emzirdiği süre içerisinde ayda kaç kez } \\
\text { cinsel ilişkiye girdiği }\end{array}$} & $1-3 \mathrm{kez}$ & 34 & 59,67 & 14,36 & KW:0,657 & 0,883 \\
\hline & $4-6 \mathrm{kez}$ & 44 & 61,22 & 8,63 & & \\
\hline & $7-9$ kez & 17 & 60,88 & 7,24 & & \\
\hline & 10 kez ve üzeri & 9 & 58,55 & 10,29 & & \\
\hline \multirow{4}{*}{$\begin{array}{l}\text { Bu güne kadar hiç doğum öncesi, gebelik sırasında veya doğum } \\
\text { sonrası dönemlerdeki cinsel yaşam hakkında bilgi alma durumu }\end{array}$} & Bilgi almayan & 10 & 59,80 & 11,86 & KW: 3,498 & 0,478 \\
\hline & Doktordan bilgi alan & 67 & 59,37 & 11,64 & & \\
\hline & Arkadaşından bilgi alan & 4 & 60,25 & 10,24 & & \\
\hline & Hemşire/ebeden bilgi alan & 23 & 63,31 & 7,55 & & \\
\hline
\end{tabular}

*KW: Kruskal-Wallis test, $\mathrm{t}$ : t testi, Z: Mann-Whitney U testi.

Kadınların \%69,2'sinin doğum sonu 41'nci günden sonra cinsel aktiviteye başladığı, \%48,1'inin doğum sonu dönemde cinsel ilişkiyi başlatmayı çoğunlukla eşinin teklif ettiği ve $\% 42,3$ 'ünün ayda 4-6 kez cinsel ilişkiye girdiği belirlenmiştir. Kadınların üçte birinin doğum sonu erken dönemde cinsel aktiviteye başladığı ve yaklaşık yarısının eşinin isteği ile birliktelik yaşadığı görülmektedir. Doğum sonu kanamanın olması, epizyotomi ya da sezaryan nedeniyle insizyon yerinde ağrı olması gibi nedenler, cinsel aktiviteye başlama süresinin uzamasında etkili olabilmektedir. Literatürde çalışma bulgusu ile benzer sonuçlar yer almaktadır. Lurie ve ark.'nın (2013) çalışmasında, vajinal yolla epizyotomisiz doğum yapanların cinsel ilişkiye başlama zamanı 4,5 $\pm 1,8$ hafta, vajinal yolla epizyotomili doğum yapanlarda $7,9 \pm 3,0$ hafta, acil sezaryen olan kadınlarda $6,1 \pm 2,4$ hafta ve kendi isteği ile sezaryen olan kadınlarda 6,1 $\pm 2,6$ hafta olarak bulunmuştur (21). TNSA 2013 verilerine göre, tüm annelerin yüzde 84 'ü doğumu takip eden ilk iki ay içinde cinsel ilişkiden kaçınmaktadır. Doğum sonrası ortanca geçici kısırlık süresi 3,3 ay, cinsel perhiz süresi 1,8 ay olarak bulunmuştur (22). Von Sydow (1999), postpartum cinsel yaşamla ilgili yapılmış çalışmaların meta analizinde, cinsel aktiviteye dönüşü Ingiltere ve Amerika'da 6-8 hafta olarak belirtmiştir (23). Şahin'in (2009) çalışmasında doğum sonu cinsel yaşama 40. günde başladıkları saptanmıştır (24).

Kadınların \%64,4'ü doktordan doğum öncesi, gebelik sırasında veya doğum sonrası dönemlerdeki cinsel yaşam hakkında bilgi aldığını belirtmiştir (Tablo 2). Bu sonuç, kadınların yaklaşık üçte birinin cinsel yaşam konusunda bilgisi olduğu şeklinde yorumlanmaktadır. Çalışmanın özel hastaneye başvuran kadınlarla yapılmış olmasının bilgilendirme oranının fazla olmasını etkilemiş olabileceği düşünülmektedir. Çalışma bulgusu ile benzer şekilde, Çoban'ın (2012) çalışmasında, kadınların \%68,5'i postpartum cinsel danışmanlık aldığını belirtmiştir (19). Değerli Kodaz'ın (2013) çalışmasında kadınların \%31,4'ü gebelik öncesi dönemde cinsel yaşam hakkında bilgi aldığını ifade etmiştir (20). Bu sonuç, çalışma bulgusundan oldukça düşüktür. Her iki çalışmanın farklı şehirlerde ve farklı özellikteki hastanelerde yapılmış olmasının sonucu etkilemiş olabileceği düşünülmektedir.

Kadınların CYKÖ puan ortalaması $60,43 \pm 10,70$ olarak bulunmuştur (Tablo 3). Literatürde farklı örneklem grupları ile yapılmış çalışma sonuçları yer almaktadır. Çoban'ın (2012), postpartum dönemdeki kadınlarda yaptığı çalışmada CYKÖ puan ortalaması $69,69 \pm 1,87$ olarak bulunmuştur (19). Yaralı́nın (2013) çalışmasında, kadınların cinsel yaşam kalitesi toplam puanlarına ilişkin aritmetik ortalama

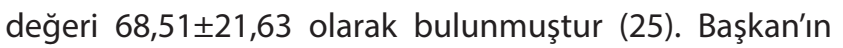
(2015), inflamutuar barsak hastalığı olan kadınlarda yap-

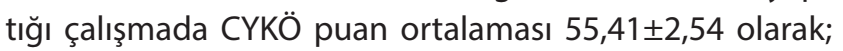
Bahıtlı'nın (2016) jinekolojik kanser tanısı konulan ve tedavisi alan kadınlarda yaptığı çalışmada CYKÖ puan ortalaması $68,93 \pm 21,17$ olarak saptanmıştır $(26,27)$. Atay'ın (2017) İnfertil kadınlarda yaptığı çalışmada "cinsel yaşam 
kalitesi" düzeyi 89,736 $\pm 9,898$; Mestoğulları́nın (2017), 18-49 yaş evli kadınlarla yaptığı çalışmada, CYKÖ puan ortalaması 74,2 $\pm 21,0$ olarak ve Soylu'nun (2017) adet düzensizliği olan kadınlarla yaptığı çalışmada CYKÖ puan orta-

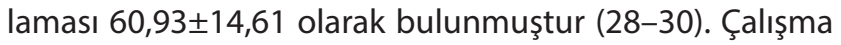
bulgusu ile literatür sonuçlarının farklı olması, örneklem gruplarının farklı olmasına bağlanmıştır.

Katılımcıların, yaş grubu, evlilik süresi, öğrenim durumu, çalışma durumu, aile tipi ve yatak odasında birlikte yatan çocuğu olma durumu ile CYKÖ puan ortalaması arasında istatistiksel açıdan anlamlı farklııık saptanmamıştır $(p>0,05)$ (Tablo 4). Literatürde çalışma bulgusundan farklı sonuçlar yer almaktadır. Çoban'ın (2012) postpartum dönemdeki kadınlarla yaptığı çalışmada, yaş grubu, öğrenim durumu, çalışma durumu ile CYKÖ puan ortalaması arasında anlamlı farklılık olduğu saptanmıştır (19).

Yaralı́nın (2013) çalışmasında, yaş, eğitim durum, meslek, evlilik süresi ile CYKÖ puan ortalaması arasında anlamlı farklılık saptanmış; aile tipi ile anlamlı farklılık saptanmamıştır (25). Değerli Kodaz'ın (2013) gebelerle yaptığı çalışmada, öğrenim durumu ve aile tipinin CYKÖ puan ortalamasını etkilemediği, çalışan kadınların puanlarının daha yüksek olduğu saptanmıştır (20). Başkan'ın (2015) çalışmasında, öğrenim düzeyi düşük, çalışmayan, geniş ailede yaşayan kadınların cinsel yaşam kalitelerinin düşük olduğu belirlenmiştir (26). Atay'ın (2017) İnfertil kadınlarda yaptığı çalışmada yaş grupları ve evlilik süresi ile CYKÖ puan ortalaması arasında anlamlı farklılık saptanmış; 26-30 yaş grubunda ve 2-5 yıldır evli olanların puanlarının en düşük olduğu görülmüştür (28). Mestoğulları́nın (2017), 18-49 yaş evli kadınlarla yaptığı çalışmada, yaş ve evlilik yılı arttıkça cinsel yaşam kalitesinin azaldığı saptanmıştır (29). Atay'ın (2017) Infertil kadınlarda yaptığı çalışmada öğrenim durumu ile "cinsel yaşam kalitesi" düzeyi arasında anlamlı farklılık saptanmamıştır (28). Sonuçların, çalışma bulgusu ile farklı olması, örneklem gruplarının farklı olmasına bağlanmıştır.

Katılımcıların, gebelik sayısı, gebeliğin istenme durumu, doğumun üzerinden geçen süre, doğum şekli ve günlük ortalama emzirme sayısı ile CYKÖ puan ortalaması arasında istatistiksel açıdan anlamlı farklılık saptanmamıştır $(p>0,05)$ (Tablo 5). Literatürde çalışma bulgusu ile benzer sonuçlar yer almaktadır. Değerli Kodaz'ın (2013) gebelerle yaptığı çalışmada, gebeliğin istenme durumunun ve doğum şeklinin cinsel yaşam kalitesini etkilemediği belirlenmiştir (20). Akyüz'ün (2009) çalışmasında, gebeliklerin planlı olma ve bebeğin istenme durumlarının kadınların doğum sonrası cinsel sorun yaşamalarını etkilemediği bulunmuştur.
Doğum sonu dönemdeki kadınların büyük bir kısmının, istatistiksel olarak benzer şekilde doğum sonrası cinsel sorun yaşadığı belirlenmiştir Kadınların doğum sonrası dönemde memelerinde oluşan değişikliklerden dolayı cinsel ilişki esnasında rahatsızlık hissettikleri, rahatsızlığı olan ve olmayan kadınların doğum sonrası benzer şekilde cinsel sorun yaşadığı belirlenmiştir (15). Şahin'in (2009) çalışmasında doğum sonu cinsel ilişkiye başlama zamanı ile emzirme arasında istatistiksel olarak anlamlı bir ilişki bulunmamıştır (24). Çalışma bulgusunun aksine, Çoban'ın (2012) postpartum dönemdeki kadınlarla yaptığı çalışmada, gebeliğin istenme durumu ile CYKÖ puan ortalaması arasında anlamlı farklılık olduğu; doğum şekli ve bebeğin emme durumu ile anlamlı farklıık olmadığı saptanmıştır $(p<0,05)(19)$.

Katılımcıların şimdiye kadar cinsel yaşamı sırasında cinsel aktiviteyi engelleyen bir durum olma durumu, gebelik öncesi ve gebelik sırasında cinsel yaşamla ilgili herhangi bir sorun yaşama durumu, doğum sonu cinsellik yaşamaya başlama zamanı, bebeğini emzirdiği süre içerisinde ayda kaç kez cinsel ilişkiye girdiği ve cinsel yaşam hakkında bilgi alma durumu ile CYKÖ puan ortalaması arasında istatistiksel açıdan anlamlı farklılık saptanmamıştır $(p>0,05)$ (Tablo 6). Çalışma bulgusu ile benzer şekilde, Değerli Kodaz'ın (2013) gebelerle yaptığı çalışmada, gebelik öncesi ve gebelik döneminde cinsellikle ilgili sorun yaşama durumunun cinsel yaşam kalitesini etkilemediği belirlenmiştir (20). Akyüz'ün (2009) çalışmasında, gebelikten önce cinsel sorunu olan ve olmayan kadınların doğum sonrası dönemde benzer şekilde cinsel sorun yaşadıkları bulunmuştur (15). Çalışma bulgusunun aksine, Çoban'ın (2012) postpartum dönemdeki kadınlarla yaptığı çalışmada, gebelik öncesi ve gebelik sırasında cinsel ilişkide sorun yaşama durumu ile CYKÖ puan ortalaması arasında anlamlı farklılık olduğu; cinsel ilişkiye başlama zamanı ile anlamlı farklılık olmadığı saptanmıştır (19).

\section{Sonuç ve öneriler}

Bu çalışmanın sonucunda, emziren kadınların CYKÖ puan ortalaması $60,43 \pm 10,70$ olarak bulunmuş ve orta düzeyde bir cinsel yaşam kalitelerinin olduğu belirlenmiştir. Kadınların demografik özelliklerinin ve emzirmeye ilişkin durumlarının cinsel yaşam kalitelerini etkilemediği sonucuna varılmıştır. Çalışma sonucunda, hemşire ve ebeler tarafından kadınlara ve eşlerine yönelik olarak gebelik öncesi, gebelik ve doğum sonrası dönemde cinsel yaşama ilişkin bilgilendirmelerin yapılması, kadınların gebelik öncesi ve sonrası dönemin birlikte değerlendirildiği, farklı değişkenler açısından, daha büyük örneklem grupları ile benzer çalışmaların yapılması önerilmektedir. 


\section{Kaynaklar}

1. Tuğrul B, Artan I. Çocukların Cinsel Eğitimi ile İlgili Anne Görüşlerinin Incelenmesi. Hacettepe Üniversitesi Eğitim Fakültesi Derg 2001;20:141-9. http://www.efdergi.hacettepe.edu.tr/yonetim/ icerik/makaleler/999-published.pdf

2. Olsson A, Lundqvist M, Faxelid E, Nissen E. Women's thoughts about sexual life after childbirth: Focus group discussions with women after childbirth. Scand J Caring Sci 2005;19:381-7. [CrossRef]

3. Özmen D, Çetinkaya A, Kuş K, Yılmaz M, Hügül Y. Manisa ilköğretim okullarında görev yapan öğretmenlerin cinsel eğitim ile ilgili tutumları. Sağlık ve Toplum 2006;2:81-9.

4. Blackburn ST, Maternal, Fetal \& Neonatal Physiology: A Clinical Perspective, 2nd ed. Philadelphia, PA: Saunders: 2003. pp.158-79.

5. Small EC. Psychosocial-sexual issues. Obstet Gynecol Clin North Am 1994;21:773-80.

6. Visness MC, Kennedy K. The frequency of coitus during breastfeeding. Birth 1997;24:253-7. [CrossRef]

7. Taşkın L. Doğum ve Kadın Sağlığı Hemşireliği, 7. Baskı. Ankara; Sistem Ofset Matbaacılık; 2005. ss.35-6.

8. Wong DL, Perry SE, Hockenberry MJ, Lowdermilk DL, Wilson D. Maternal Child Nursing Care, 3rd ed. St. Louis: Mosby Inc.; 2006. pp.1172-4.

9. Masters WB, Johnson VE. Human Sexual Behavior. İnsanda Cinsel Davranış (Çev. Ed: Sayın Ü). Bilimsel ve Teknik Yayınlar Çevir Vakfı, İstanbul, 1994. ss.7-8.

10. Avery DM, Duckett L, Frantzich CR. The experience of sexuality during breastfeeding. J Midewifery Womens Health 2000;45:227-37. [CrossRef]

11. Alder E, Cook A, Davidson D, West C, Bancroft J. Hormones, mood and sexuality in lactating women. Br J Psychiatry 1986;148:74-9. [CrossRef]

12. Hyde JS, DeLamater JD, Plant EA, Byrd JM. Sexuality during pregnancy and the year postpartum. J Sex Res1996;33:143-51. [CrossRef]

13. Barett G, Pendry E, Peacock J, Victor C, Thankor R, Manyoda I. Sexual health after childbirth. Br J Obstet Gynaecol 2000;107:186-95. [CrossRef]

14. Alhborg T, Dahlöf LG, Hallberg LR. Quality of intimate and sexual relationship in first-time parents six months after delivery. J Sex Res 2005;42:167-74. [CrossRef]

15. Akyüz EÖ. Doğum Sonrası Cinsel Sorunlar ve Etkileyen Etmenlerin Incelenmesi (Tez), Adnan Menderes Üniversitesi Sağlık Bilimler Enstitüsü Doğum-Kadın Sağlığı ve Hastalıkları Hemşireliği Anabilim Dalı Yüksek Lisans Tezi, 2009.

16. La Marre AK, Peterson LQ, Gorzalka BB. Breastfeeding and postpartum maternal sexual functioning: A review. Canadian J Hum Sex 2003;12:151-65. http://www.binik-lab.com/pdf/8.pdf

17. Yörük F. Doğum Sonrası Dönemdeki Kadınların Cinsel Problemlerinin Çözümünde Plıssıt Modelin Etkinliği (Tez), Adnan Menderes Üniversitesi Sağlık Bilimler Enstitüsü Doğum-Kadın Sağlığı Ve Hastalıkları Hemşireliği Anabilim Dalı Yüksek Lisans Tezi, 2013.
18. Tuğut N, Gölbaşı Z. Cinsel Yaşam Kalitesi Ölçeği - Kadın Türkçe versiyonunun geçerlik ve güvenirlik çalışması. Cumhuriyet Tıp Derg 2010;32:172-80. https://dergipark.org.tr/tr/download/ article-file/47694

19. Çoban V. Postpartum dönemdeki kadınların cinsel yaşam kalitesi ve etkileyen faktörler (Tez). Cumhuriyet Üniversitesi, Sağlık Bilimleri Enstitüsü Doğum ve Kadın Hastalıkları Hemşireliği Anabilim Dalı Yüksek Lisans Tezi, 2012.

20. Değerli Kodaz N. Gebelikte Cinsel Yaşam Kalitesi Ve Illişkili Faktörler (Tez). Selçuk Üniversitesi, Sağlık Bilimleri Enstitüsü Hemşirelik Anabilim Dalı Yüksek Lisans Tezi, 2013.

21. Lurie S, Aizenberg M, Sulema V, Boaz M, Kovo M, Golan A, Sadan O. Sexual function after childbirth by the mode of delivery: a prospective study. Arch Gynecol Obstet 2013;288:785-92. [CrossRef]

22. Hacettepe Üniversitesi Nüfus Etütleri Enstitüsü. 2013 Türkiye Nüfus ve Sağlık Araştırması. Ankara: Hacettepe Üniversitesi Nüfus Etütleri Enstitüsü, T. C. Kalkınma Bakanlığı ve TÜBiTAK; (2014). ss.110-1. http://www.hips.hacettepe.edu.tr/tnsa2013/rapor/TNSA_2013_ ana_rapor.pdf

23. von Sydow K. Sexuality during pregnancy and after childbirth: A meta -content analysis of 59 studies. JPsychosom Res 1999;47:2749. [CrossRef]

24. Şahin N. Kadınlarda postpartum dönemde cinsel yaşam. Zeynep Kamil Tıp Bülteni 2009;40:125-30. https://dergipark.org.tr/tr/ download/article-file/205440

25. Yaralı S. Evli Kadınlarda Cinsel Fonksiyon Bozuklukları Ve Cinsel Yaşam Kalitesinin İncelenmesi (Tez). Atatürk Üniversitesi, Sağlık Bilimleri Enstitüsü Halk Sağlığı Hemşireliği Anabilim Dalı Yüksek Lisans Tezi, 2013.

26. Başkan B. İnflamutuar barsak hastalığı olan kadınlarda cinsel yaşam kalitesinin değerlendirilmesi (Tez). Marmara Üniversitesi, Sağlık Bilimleri Enstitüsü İç Hastalıkları Hemşireliği Anabilim Dalı Yüksek Lisans Tezi, 2015.

27. Bahıtlı B. Jinekolojik Kanser Tanı ve Tedavisine Illişkin Bazı Özelliklerin Kadınların cinsel Yaşam Kalitesine etkisi (Tez). Dokuz Eylül Üniversitesi, Sağlık Bilimleri Enstitüsü Doğum ve Kadın Hastalıkları Hemşireliği Anabilim Dalı Yüksek Lisans Tezi, 2016.

28. Atay Y. Infertilite Tedavisi Gören Kadınların cinsel Yaşam Kalitesi, İlişkilerindeki Mutluluk Düzeyi ve Etkileyen Faktörler (Tez). Okan Üniversitesi, Sağlık Bilimleri Enstitüsü Hemşirelik Anabilim Dalı Yüksek Lisans Tezi, 2017.

29. Mestoğulları E 18-49 yaş arası üreme çağındaki evli kadınların cinsel fonksiyonlarından memnuniyet durumu, cinsel semptomları ve bu semptomların cinsel yaşam kalitesi üerine etkisi (Tez). Trakya Üniversitesi, Sağlık Bilimleri Enstitüsü Hemşirelik Anabilim Dalı Yüksek Lisans Tezi, 2017.

30. Soylu T. Adet düzensizliği olan kadınların cinsel yaşam kalitesi ve evlilik uyumunun incelenmesi (Tez). Çukurova Üniversitesi, Sağlık Bilimleri Enstitüsü Hemşirelik Anabilim Dalı Yüksek Lisans Tezi, 2017. 